\title{
Stress and Internet Addiction in College Students During the COVID-19 Pandemic
}

\section{Muhammad Hamami*, Gevald Galant Abdul Aziz, and Mochammad Sa'id}

Faculty of Psychology, State University of Malang, Malang

\section{ORCID}

Muhammad Hamami; https://orcid.org/0000-0003-2418-5110

Abstract. The COVID-19 pandemic has affected many facets of life. The rising usage of the internet, particularly social media platforms, is one of them. Individuals who use the internet more frequently may develop an internet addiction. This study aimed to investigate the relationship between stress and internet addiction in college students. This study utilized a survey-based correlational quantitative approach. The sample consisted of 81 students from the State University of Malang. The instruments utilized in this study were the Perceived Stress Scale-10 modified for COVID-19 to measure stress related to the COVID-19 pandemic, and the Internet Addiction Test to measure internet addiction. Data were analyzed using product moment correlation techniques.

Corresponding Author: Muhammad Hamami; email: m.azhar.1908116@student. um.ac.id

\section{Dates}

Published 28 January 2022

Publishing services provided by Knowledge E

(c) Muhammad Hamami et al. This article is distributed under the terms of the

Commons Attribution License, which permits unrestricted use and redistribution provided that the original author and source are credited.

Selection and Peer-review unde the responsibility of the ICoPsy Conference Committee.

\section{G OPEN ACCESS} The study's findings revealed a substantial positive relationship between stress from the COVID-19 pandemic and internet addiction in college students $(r=0.333 ; p=$ 0.002). This implies that the higher the stress level related to the COVID-19 pandemic experienced by an individual, the higher the tendency for internet addiction.

Keywords: stress, internet addiction, COVID-19 pandemic, college students

\section{Introduction}

To limit physical contact during the COVID-19 pandemic, most activities must be conducted online. Regulations governing study from home have been implemented at all levels of education. Despite the concerns of many parents and teachers, this strategy is thought to be the most successful for facilitating learning [1]. In several studies, students, as well as parents and teachers, who experience this learning approach, reported feeling stressed $[2,3]$. Stress is a complex issue during a pandemic because students will be forced to adjust to new circumstances and a new way of life, increasing the strain of processing information. Lack of quality sleep, easy anxiety and fear, headaches, and poor time management are all symptoms of this stressful situation [4-6].

It is undeniable that social media is an inseparable part of student academic life during the COVID-19 pandemic. During a pandemic, social media is used to address information needs for clarity and as a kind of entertainment [7]. According to the Indonesian Datereportal data for 2020 and 2021, the number of people using the internet in Indonesia increased from 175 million to 202 million. Surprisingly, the 18-24 
year old age group is Indonesia's second largest group of internet users, trailing only the 25-34 year olds. The figures are practically identical to those released by the Indonesian Internet Service Providers Association (APJII) in 2020, which show that the 20-24 age group is Indonesia's most active internet user.

Most students utilize social media to solve problems, entertain themselves, and develop social interactions [8]. According to another study, students' sentiments of Ioneliness and FOMO had an impact on their proclivity to use the internet [9]. It's unsurprising that video streaming services like Iqiyi, Netflix, and Youtube have already seen their traffic increase from a few dozen to hundreds of percent during the pandemic [10]. Other social media platforms, such as WhatsApp and Instagram, saw a similar rise [11].

One thing to remember is that excessive social media use (more than 6 hours per day) can contribute to the establishment of internet addiction [12]. In recent years, numerous labels have been used to describe internet addiction disorder (IAD) or online addiction. Problematic Internet Use (PIU) is a word invented by some researchers to describe a variety of maladaptive behaviors such as Internet Dependency [13], Compulsive Internet Use [14], and others that refer to addictive behavior towards social media or gadgets over a long period of time.

Based on the description above, it is possible to assume that internet addiction among students is induced by stress during the pandemic, which has resulted in increasing use of the internet as a medium for coping with stress. As a result, the purpose of this study is to dig deeper into the relationship between stress related to the COVID-19 pandemic and internet addiction in college students.

\section{Literature review}

In comparison with the research that we will do in the period COVID-19 we try to include studies which explain the relation between stress and internet addiction in Indonesia. What needs to be highlighted in our research is that the stress we are looking at is not academic stress, which is only concerned with student life in college. The stress that we investigate is the more frequent stress associated to the COVID-19 pandemic that people experience at home, college, and in social environments. We were able to acquire 6 journal articles that explored stress and internet addiction during the COVID19 pandemic in details, as shown in table 1.

Table 1 shows that during the COVID-19 pandemic, several studies on stress and internet addiction centered on online game addiction $[16,17,20]$. Another study identified 
TABLE 1: Research description of internet addiction due to stress during the Covid-19 pandemic

\begin{tabular}{|c|c|c|c|c|c|}
\hline No. & esearch & $\begin{array}{l}\text { search } \\
\text { oject }\end{array}$ & Data collection & Variable & Results \\
\hline 1. & $\begin{array}{l}\text { Simanjutak } \\
\text { \& Ko (2021). } \\
\text { Makara Human } \\
\text { Behavior } \\
\text { Studies in Asia, } \\
\text { 25(1), 80-95. [15] }\end{array}$ & $\begin{array}{l}449 \text { Indonesian } \\
\text { female workers } \\
\text { in Taiwan }\end{array}$ & $\begin{array}{l}\text { Questionnaires } \\
\text { regarding Internet } \\
\text { Addiction Test (IAT), } \\
\text { Perceived Stress } \\
\text { Scale (PSS), and } \\
\text { the Brief COPE for } \\
\text { adaptive coping } \\
\text { subscale }\end{array}$ & $\begin{array}{l}\text { Internet } \\
\text { Addiction, } \\
\text { Neuroticism, } \\
\text { Perceived } \\
\text { Stress, dan } \\
\text { Adaptive } \\
\text { Coping Style }\end{array}$ & $\begin{array}{l}\text { There is a positive } \\
\text { relationship } \\
\text { between stress and } \\
\text { internet addiction } \\
(r=0.399)(p<0.01)\end{array}$ \\
\hline & $\begin{array}{l}\text { Gewab et al } \\
\text { (2020). Jurnal } \\
\text { Biomedika, 2(2), } \\
\text { 117-123.[16] }\end{array}$ & $\begin{array}{l}56 \text { teenagers } \\
\text { aged } 16-17 \text { years } \\
\text { in Surakarta. }\end{array}$ & $\begin{array}{l}\text { Questionnaires } \\
\text { regarding Internet } \\
\text { Addiction Test (IAT), } \\
\text { Smoking Behavior } \\
\text { Questionnaire, } \\
\text { and Depression, } \\
\text { Anxiety, Stress } \\
\text { Scale (DASS). }\end{array}$ & $\begin{array}{l}\text { Stress, } \\
\text { smoking } \\
\text { behavior, and } \\
\text { online game } \\
\text { addiction }\end{array}$ & $\begin{array}{l}\text { There is a significant } \\
\text { relationship } \\
\text { between smoking } \\
\text { and online game } \\
\text { addiction with } \\
\text { adolescent stress } \\
(p=0.018)\end{array}$ \\
\hline & $\begin{array}{l}\text { Agatha, Cindy } \\
\text { Monika (2020). } \\
\text { Thesis, } \\
\text { University of } \\
\text { Pelita Harapan. } \\
\text { [17] }\end{array}$ & $\begin{array}{lr}3135 & \text { online } \\
\text { game players } \\
\text { aged } 18- \\
35 \text { years } \\
\text { throughout } \\
\text { Indonesia }\end{array}$ & 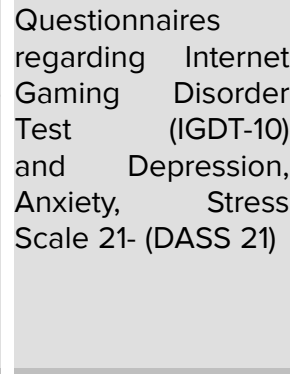 & $\begin{array}{l}\text { Online game } \\
\text { addiction, } \\
\text { depression, } \\
\text { anxiety, and } \\
\text { stress }\end{array}$ & $\begin{array}{l}\text { There is a significant } \\
\text { relationship } \\
\text { between online } \\
\text { game addiction } \\
\text { and mental health } \\
\text { problems such } \\
\text { as depression } \\
(p<0.00) \text {, anxiety } \\
(p<0.001) \text {, and } \\
\text { stress }(p<0.05) \text {. }\end{array}$ \\
\hline 4. & $\begin{array}{l}\text { Jatmika, Devi } \\
\text { (2020) Seminar } \\
\text { Nasional } \\
\text { Psikologi Positif } \\
\text { 2020, 28, } 268 \\
{[18]}\end{array}$ & $\begin{array}{lr}165 & \text { students } \\
\text { aged } & 16-25 \\
\text { years in Jakarta }\end{array}$ & $\begin{array}{l}\text { Questionnaires } \\
\text { regarding } \\
\text { Depression } \\
\text { Anxiety Stress } \\
\text { Scale 21-(DASS-21) } \\
\text { and Generalized } \\
\text { Problematic Internet } \\
\text { Use Scale-2 (GPIUS- } \\
\text { 2). }\end{array}$ & $\begin{array}{l}\text { lological } \\
\text { ss dan } \\
\text { ematic } \\
\text { et use }\end{array}$ & $\begin{array}{l}\text { There is a positive } \\
\text { relationship } \\
\text { between } \\
\text { psychological } \\
\text { distress and } \\
\text { problematic internet } \\
\text { use. }(r=0.442)(p=< \\
0.01)\end{array}$ \\
\hline 5. & $\begin{array}{l}\text { Nurmalasari, } \\
\text { Yuli (2020). } \\
\text { Indonesian } \\
\text { Journal of } \\
\text { Guidance and } \\
\text { Counseling, 9(1), } \\
\text { 46-51. [19] }\end{array}$ & $\begin{array}{l}103 \text { junior high } \\
\text { school students } \\
\text { in Bandung }\end{array}$ & $\begin{array}{l}\text { Compulsive Internet } \\
\text { Use Scale (CIUS) } \\
\text { Questionnaire }\end{array}$ & $\begin{array}{l}\text { Loss of } \\
\text { Control, } \\
\text { Withdrawal } \\
\text { symptomps, } \\
\text { Coping, } \\
\text { Salience, } \\
\text { Conflict, } \\
\text { Lying to hide } \\
\text { internet use }\end{array}$ & $\begin{array}{l}\text { Three dominant } \\
\text { indicators that tend } \\
\text { to indicate the level } \\
\text { of compulsiveness } \\
\text { consist of: loss of } \\
\text { control (23.52), } \\
\text { withdrawal } \\
\text { symptoms (20.02), } \\
\text { and coping (19.78). }\end{array}$ \\
\hline & 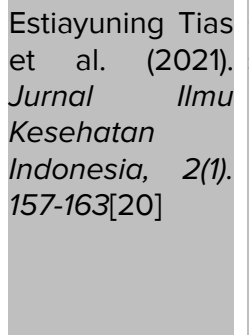 & $\begin{array}{l}66 \text { junior high } \\
\text { school students } \\
\text { in Padang }\end{array}$ & $\begin{array}{l}\text { Questionnaires } \\
\text { regarding } \\
\text { Depression Anxiety } \\
\text { Stress Scale 42- } \\
\text { (DASS-42) and } \\
\text { Indonesian Online } \\
\text { Game Addiction } \\
\text { Questionnaire } \\
\text { (IRAQ) }\end{array}$ & $\begin{array}{l}\text { Online game } \\
\text { addiction and } \\
\text { stress }\end{array}$ & $\begin{array}{l}\text { There is a significant } \\
\text { relationship } \\
\text { between stress and } \\
\text { the level of online } \\
\text { game addiction } \\
(p=0.044)\end{array}$ \\
\hline
\end{tabular}


three key psychological indicators in those who use devices and in individuals who are not even students $[15,19]$. There is only one study that is comparable to our study, and it is on psychological distress and problematic internet use among students in Jakarta[18]. However, those studies continue to employ a general stress scale rather than a stress scale designed particularly to quantify the stress experienced by people affected by the COVID-19 pandemic.

\section{Method}

This study is a correlational quantitative study with a survey as the primary data collection method. This study aimed to determine the relationship between stress related to the COVID-19 pandemic and internet addiction on college students. The participants in this study were 81 students from the State University of Malang, ranging in age from 18 to 23 years. The participants were chosen by an accidental sampling technique. The instruments used in this study were the modified Perceived Stress Scale-10 for COVID19 (PSS-10-C) to measure stress related to the COVID-19 pandemic, and the Internet Addiction Test (IAT) was utilized to measure internet addiction. Both instruments have been translated into Indonesian previously. Participants were also requested to fill out a self-description form. Product Moment correlation was used to examine the research data.

\section{Result and Discussion}

\subsection{Result}

According to the table 2 , the majority of responses are female students (81.5\%), with the class of $2019(40.7 \%)$ and an age range of 20 years $(38.3 \%)$. The majority of the participants (47.5\%) were from the Faculty of Psychology Education at the State University of Malang. During the pandemic, social media usage was quite high, ranging from 6 to 10 hours per day (42.5\%) and having 4 to 5 social media accounts (42.5\%). The WhatsApp application, on the other hand, is a popular choice among respondents today (47.5\%) 
TABLE 2: Demography data

\begin{tabular}{|c|c|c|c|}
\hline \multirow[t]{3}{*}{ Category } & Type & $\mathrm{N}$ & $\%$ \\
\hline & 18 years & 3 & 3,7 \\
\hline & 19 years & 24 & 29,6 \\
\hline \multirow[t]{4}{*}{ Age } & 20 years & 31 & 38,3 \\
\hline & 21 years & 18 & 22,2 \\
\hline & 22 years & 4 & 4,9 \\
\hline & 23 years & 1 & 1,3 \\
\hline Total & & 81 & 100 \\
\hline \multirow[t]{2}{*}{ Sex } & Man & 15 & 18,5 \\
\hline & Woman & 66 & 81,5 \\
\hline Total & & 81 & 100 \\
\hline \multirow[t]{4}{*}{ Class } & 2017 & 5 & 6,2 \\
\hline & 2018 & 15 & 18,5 \\
\hline & 2019 & 33 & 40,7 \\
\hline & 2020 & 28 & 34,6 \\
\hline Total & & 81 & 100 \\
\hline \multirow[t]{8}{*}{ Faculty } & FPPsi & 38 & 47,5 \\
\hline & FIP & 13 & 16,2 \\
\hline & FMIPA & 9 & 11,2 \\
\hline & FIK & 2 & 2,5 \\
\hline & FEB & 5 & 6,2 \\
\hline & FIS & 9 & 11,2 \\
\hline & FS & 3 & 3,7 \\
\hline & FT & 1 & 1,2 \\
\hline Total & & 80 & 98,76 \\
\hline \multirow[t]{4}{*}{ Number of Social Media } & $<4$ & 8 & 10 \\
\hline & $4-5$ & 34 & 42,5 \\
\hline & $6-7$ & 26 & 32,5 \\
\hline & $>7$ & 10 & 12,5 \\
\hline Total & & 81 & 100 \\
\hline \multirow[t]{4}{*}{ Duration of Social Media Usage per day } & $<1$ hour & 4 & 5 \\
\hline & $1-5$ hours & 27 & 33,75 \\
\hline & $6-10$ hours & 34 & 42,5 \\
\hline & $>10$ hours & 15 & 18,7 \\
\hline Total & & 81 & 98,76 \\
\hline \multirow[t]{10}{*}{ Frequently used apps } & Facebook & 2 & 2,4 \\
\hline & Instagram & 19 & 22,6 \\
\hline & Whatsapp & 38 & 47,5 \\
\hline & Tiktok & 12 & 14,3 \\
\hline & Pinterest & 1 & 1,2 \\
\hline & Webtoon & 1 & 1,2 \\
\hline & Wevers & 1 & 1,2 \\
\hline & Youtube & 1 & 1,2 \\
\hline & Line & 1 & 1,2 \\
\hline & Twitter & 8 & 9,5 \\
\hline Total & & 81 & 100 \\
\hline
\end{tabular}


TABLE 3: Variables of stress levels in students at the State University of Malang in year 2021.

\begin{tabular}{l|c|c|}
\hline Stress Level & Frequency & $\%$ \\
\hline Low Stress & 1 & 1,2 \\
\hline Moderate Stress & 56 & 69,1 \\
\hline Severe stress & 24 & 29,6 \\
\hline Total & 81 & 100 \\
\hline
\end{tabular}

TABLE 4: Stressors felt during the COVID-19 pandemic

\begin{tabular}{|c|c|c|c|}
\hline Category & Type & N & $\%$ \\
\cline { 2 - 4 } & Restrictions & 17 & 20,9 \\
& Boredom/saturated & 15 & 18,5 \\
\hline \multirow{4}{*}{ Stressor } & Social media & 14 & 17,2 \\
\cline { 2 - 4 } & Assignments & 10 & 12,3 \\
\cline { 2 - 4 } & overthinking & 7 & 8,6 \\
\hline & Money & 7 & 8,6 \\
\hline Total & Self Management & 6 & 7,4 \\
\hline & External Interference & 5 & 6,1 \\
\hline
\end{tabular}

\subsubsection{Stress level}

The table 3 shows the distribution of stress levels among students at the State University of Malang

Table 9. shows that $98 \%$ of students at the State University of Malang during the pandemic in 2021 experienced stress. Most students experienced moderate stress with a percentage (69.1\%). There is also a significant level of stress of $29 \%$.

During the COVID-19 pandemic, students experienced a variety of stressors, as seen in Table 4. We may derive eight basic stressor division themes from the 81 responses. The most prevalent pressures for college students are social restrictions (20.9\%). Due of social restrictions, some students complained that they were unable to leave the house and felt isolated. Then followed by boredom due to a lack of activities (18.5\%), distractions and information from social media (17.2\%), lecture assignments and organization $(12.3 \%)$, a need of money $(8.6 \%)$, overthinking $(8.6 \%)$, lack of selfmanagement (7.4\%), and external disturbances, such as poor signaling and a less conducive house (6.3\%). 
TABLE 5: Internet Addiction Variable in Malang State University students.

\begin{tabular}{|c|c|c|}
\hline $\begin{array}{l}\text { Internet Addiction } \\
\text { Level }\end{array}$ & Frequency & $\%$ \\
\hline $\begin{array}{l}\text { Normal Internet } \\
\text { Usage }\end{array}$ & 26 & 32,1 \\
\hline $\begin{array}{l}\text { Mild Internet } \\
\text { Addiction }\end{array}$ & 33 & 40,7 \\
\hline $\begin{array}{l}\text { Moderate Internet } \\
\text { Addiction }\end{array}$ & 22 & 27,2 \\
\hline Total & 81 & 100 \\
\hline
\end{tabular}

TABLE 6: The results of the correlation between stress and internet addiction in students at the State University of Malang in 2021

\begin{tabular}{l} 
Variable \\
Internet Addiction \\
Stress \\
\hline
\end{tabular}

Analysis
Pearson Correlation
Sig (2-tailed)
N
Pearson Correlation
Sig (2-tailed)
N

\begin{tabular}{|c|}
\hline Internet Addiction \\
\hline 1 \\
\hline 81 \\
\hline .333 \\
.002 \\
\hline 81 \\
\hline
\end{tabular}

Stress
.333
.002
81
1

81

\subsubsection{Internet addiction}

The table below shows the distribution of internet addiction among State University of Malang students in 2021. According to table 5, 40.7\% of students at the State University of Malang in 2021 suffered mild internet addiction. While 27\% of participants had moderate internet addiction and $32 \%$ had normal internet use.

\subsubsection{The correlation between the two variables}

The following are the findings of the correlation test performed with statistic program help for Windows version 25 and the product moment correlation.

Results of the Product Moment Correlation test: $r=0.333, p=0.002$. Table 6 demonstrates a correlation coefficient $(r)$ of 0.333 between internet addiction and stress levels, with a significance level of 0.002 . It states that there is a weak positive relationship between internet addiction and stress, and that the correlation is significant because $p$ $0.05(0.0020 .05)$. 


\subsection{Discussion}

Stress is defined as pressure or worry caused by the problems in somebody's life, according to the Oxford Learner's Dictionaries. Meanwhile, stress is defined by the $\mathrm{KBBI}$ as a mental or emotional disturbance or disorder brought on by external factors. Another definition is stress as a physical and psychological response to pressure or demands that manifests itself as a sensation of discomfort, distress, or depression [21]. It term explain how an individual responds to stress depends on social support and personality [22].

One of the most frequent complaints during this pandemic is stress. We discovered the following stressors in students: (1) social restrictions that limit their socialization, (2) boredom with monotonous and limited activities, (3) interference from social media such as chat notifications and hoax information, (4) coursework and organization, (5) need for money and work, (6) overthinking of future conditions, and (7) lack of self-management, such as (difficulty managing time and studying, and lastly (8) external distractions, such as unfavorable signals and home atmosphere. The stressors we receive are consistent with several studies, including Hamzah and Rahmawati's research, which identifies the lecture burden as a stress factor for students, and Kartika's research, which identifies lecture assignments, an unfavorable environment, inability to meet loved ones, and a limited internet network as the main stressors for students $[23,24]$.

Table 3 shows that the majority of students at State University of Malang had moderate stress levels ( $n=56)$, followed by high stress levels $(n=24)$, and finally low stress levels $(n=1)$. Many factors influence a person's high and low stress levels. Optimism that everything will go well and great self-confidence in one's ability to overcome difficulties can both influence a person's stress level [25]. Furthermore, how an individual respond to stress is influenced by social support and personality [22]. Students who do not receive adequate social support, are not acknowledged, and are not supported will experience distress, resulting in a high level of stress [26]. Students with ambivert and extrovert personalities, on the other hand, may find it difficult to fit in $[27,28]$. This is because extroverted students are more likely to rush and solve problems impulsively, making them more prone to poor academic performance [29].

Individuals must adjust to a variety of stressors in order to have a positive emotional and physiological response. Coping is the term for this adjustment process, which is separated into two types: problem-focused coping and emotion-focused coping. In his publication, Wade et. al. states that handling that focuses on emotions necessitates individuals' ability to accept and feel emotional feelings before deciding to lessen those 
sentiments [25]. While problem-focused management necessitates an understanding of the core of the problem at hand and the proposed solution. During the pandemic, emotional focused coping in college students includes diversion behavior such as watching movies, listening to music, window shopping, and playing online games [30]. Some further said that stress caused students to use gadgets to access social media as a coping mechanism to enhance their happiness during the pandemic $[31,32]$.

The terminology of internet addiction is still a source of debate. Internet addiction is combined with internet gaming addiction in DSM-5, and the addition of internet addiction to the International Classification of Diseases (ICD-11) is still being challenged by some experts, who believe it is overly biased and lacking in detail (Higuchi et al, 2017 ). In this study, the longest duration used by students in accessing social media was $>10$ hours $(n=15)$, then $6-10$ hours $(n=34), 1-5$ hours ( $n=27)$, and finally $<1$ hours $(n=5)$. Until now, there have been disagreements about whether someone is addicted based only on the length of time spent on social media or the internet. Some researchers recommend safe internet usage limits, which are no more than 8 hours [33], 6 hours [12], and 2 hours [34].

Furthermore, the diagnostic criteria for internet addiction are currently under discussion. There are criteria from Kimberly Young, Mark Griffiths, Jerald Blok, and Ran Tao, according to Poli. We used a questionnaire from Kimberly Young with the following criteria in order to write this article: (1) Time spent on the internet; (2) Not satisfied when you stop using the internet; (3) Likes to spend time on the internet; (4) Fails when attempting to stop using the internet; (5) Being online for longer than intended; (6) Giving up something important because of the Internet; (7) Lying to hide their internet activities; (8) Using the Internet to relieve dysphoric mood (feelings of helplessness, guilt, anxiety, depression).

The description of internet addiction of students at State University of Malang is in table 5. A total of 33 respondents (40.7 \%) had a low level of addiction, 26 (32.1\%) had no addiction, and 22 (27.2 \%) had a moderate level of addiction. Table 12 shows the correlational study of internet addiction and stress levels. The correlation coefficient ( $r$ ) for both is 0.333 in the table, with a significance level ( $p$ ) of 0.002 . This indicates that stress is only related to $33.3 \%$ of the emergence of internet addiction; the remaining $66.6 \%$ is due to other variables. It can be concluded that there is a positive relationship between stress and internet addiction in Malang State University students, however the relationship remains weak. 


\section{References}

[1] Hidayat W. DAMPAK PEMBELAJARAN DARING TERHADAP GURU DAN ORANG TUA SISWA [Internet]. stit-alkifayahriau.ac.id. 2021 [cited 2021 Dec 19]. Available from: https://www.stit-alkifayahriau.ac.id/dampak-pembelajaran-daringterhadap-guru-dan-orang-tua-siswa/

[2] Wahyu A, Simanullang RH. Student Stress Due to Online Learning During the Covid19 Pandemic. J Sci n.a. 2020 Dec 9;5(2):153-7. doi: 10.30604/jika.v5i2.346

[3] JANNAH M. PENGARUH PEMBELAJARAN VIA ONLINE SELAMA PANDEMI COVID19 TERHADAP TINGKAT STRESS MAHASISWA TINGKAT AKHIR FAKULTAS KEDOKTERAN UNIVERSITAS MUHAMMADIYAH MAKASSAR [Undergraduate Thesis]. [Makasar]: Universitas Muhammadiyah Makasar;

[4] Maisa EA, Andrial A, Murni D, Sidaria S. Hubungan Stres Akademik dengan Kualitas Tidur Mahasiswa Keperawatan Tingkat Akhir Program Alih Jenjang. JIUBJ. 2021 Feb 10;21(1):438. doi: 10.33087/jiubj.v21i1.1345

[5] Son C, Hegde S, Smith A, Wang X, Sasangohar F. Effects of COVID-19 on College Students' Mental Health in the United States: Interview Survey Study. J Med Internet Res. 2020 Sep 3;22(9):e21279. doi: 10.2196/21279

[6] Syahputri VN, Rahma EA, Setiyana R, Diana S, Parlindungan F. Online learning drawbacks during the Covid-19 pandemic: A psychological perspective. EnJourMe (English Journal of Merdeka): Culture, Language, and Teaching of English. 2020;5(2):108-16. doi:10.26905/ enjourme.v5i2.5005

[7] Rohmah NN. Media Sosial sebagai Media Alternatif Manfaat dan Pemuas Kebutuhan Informasi Masa Pandemik Global Covid 19 (Kajian Analisis Teori Uses and Gratification). Al-l'lam: Jurnal Komunikasi dan Penyiaran Islam. 2020;4(1):1-16. https://doi.org/10.31764/jail.v4i1.2957

[8] Miftahurrahmah H, Harahap F. Hubungan Kecanduan Sosial Media dengan Kesepian pada Mahasiswa. AP. 2020 Oct 15;2(2):153-60. http://dx.doi.org/10.21831/ap.v2i2.34544

[9] Zanah FN, Rahardjo W. Peran kesepian dan fear of missing out terhadap kecanduan media sosial: Analisis regresi pada mahasiswa. Persona. 2020 Dec 25;9(2):286-301. doi: 10.30996/persona.v9i2.3386

[10] Pusparisa Y. Durasi Streaming Video Meningkat Belasan hingga Ratusan Persen selama Pandemi [Internet]. Databoks. 2020 [cited 2021 Dec 19]. Available from: https://databoks.katadata.co.id/datapublish/2020/10/23/durasi-streamingvideo-meningkat-belasan-hingga-ratusan-persen-selama-pandemi 
[11] Kemp S. Digital in Indonesia: All the Statistics You Need in 2021 [Internet]. DataReportal - Global Digital Insights. 11 Feb 2021 [cited 2021 Dec 19]. Available from: https://datareportal.com/reports/digital-2021-indonesia

[12] Gunawan R, Aulia S, Supeno H, Wijanarko A, Uwiringiyimana JP, Mahayana D. Adiksi Media Sosial dan Gadget bagi Pengguna Internet di Indonesia. Tehno-Socio Ekonomika. 2021 Apr 30;14(1):1. doi: 10.32897/techno.2021.14.1.544

[13] Wang W. Internet dependency and psychosocial maturity among college students. International Journal of Human-Computer Studies. 2001 Dec;55(6):919-38. doi: 10.1006/ijhc. 2001.0510

[14] Quiñones-García C, Korak-Kakabadse N. Compulsive internet use in adults: A study of prevalence and drivers within the current economic climate in the UK. Computers in Human Behavior. 2014 Jan;30:171-80. doi: 10.1016/j.chb.2013.08.004

[15] Simanjutak EJ, Ko H-C. Moderated-Mediation Roles: Relationship between Internet Addiction, Neuroticism, Perceived Stress, and Adaptive Coping Style among Indonesian Migrant Workers in Taiwan. Makara Hubs-Asia. 2021 Jul 31;25(1):80-95. doi: 10.7454/hubs.asia.1160321

[16] Gewab BTPA, Risanti ED, Herawati E, Mahmudah N. HUBUNGAN ADIKSI GAME ONLINE DAN MEROKOK DENGAN STRES PADA REMAJA. Biomedika. 2020 Aug 30;12(2):117-23. doi: 10.23917/biomedika.v12i2.10737

[17] Agatha CM. Hubungan adiksi game online dengan kesehatan mental [Internet] [bachelor thesis]. [ Jakarta]: Universitas Pelita Harapan; 2020 [cited 2021 Dec 19]. Available from: http://repository.uph.edu/11268/

[18] Jatmika D. HUBUNGAN ANTARA PSYCHOLOGICAL DISTRESS DAN PROBLEMATIC INTERNET USE PADA MAHASISWA. Seminar Nasional Psikologi UM [Internet]. Malang, Indonesia. 2020 Aug 12 [cited 2021 Dec 19];1(1). Available from: http://conference.um.ac.id/index.php/psi/article/view/39

[19] Nurmalasari Y. Indikator Dominan pada Perilaku Kompulsif Remaja dalam Mengakses Internet. Indonesian Journal of Guidance and Counseling: Theory and Application. 2020 Jun 30;9(1):46-51. doi: 10.15294/ijgc.v9i1.39276

[20] Tias E, Liza RG, Sahputra RE. Hubungan Stres dengan Tingkat Kecanduan Game Online pada Siswa SMPN 5 Padang. Jurnal IImu Kesehatan Indonesia. 2021 Jul 30;2(1):157-63. doi: 10.25077/jikesi.v2i1.170

[21] Hawari D. Manajemen stress, cemas dan depresi. Jakarta: Fakultas Kedokteran Universitas Indonesia; 2001. 225 p.

[22] Winta MVI, Syafitri AK. COPING STRESS PADA IBU YANG MENGALAMI KEMATIAN ANAK. J Philanthropy: Psy. 2019 Jul 25;3(1):14. doi: 10.26623/philanthropy.v3i1.1513 
[23] B H, Hamzah R. FAKTOR-FAKTOR YANG BERHUBUNGAN DENGAN TINGKAT STRES AKADEMIK PADA MAHASISWA STIKES GRAHA MEDIKA. Indo J HeSci. 2020 Sep 1;4(2):59. doi: 10.24269/ijhs.v4i2.2641

[24] Kartika R. ANALISIS FAKTOR MUNCULNYA GEJALA STRES PADA MAHASISWA AKIBAT PEMBELAJARAN JARAK JAUH DI MASA PANDEMI COVID-19 [Internet]. PsyArXiv; 2020 Dec 23 [cited 2021 Dec 20]. Available from: https://osf.io/nqesb

[25] Wade C, Tavris C, Swinkels A. Psychology. London: Pearson; 2016. 744 p.

[26] Salmon AG, Santi DE. Dukungan Sosial Dengan Stres Akademik Mahasiswa Perantau Dalam Pembelajaran Daring Di Masa Pandemi Covid-19. Seminar Nasional Psikologi UM. Malang, Indonesia. 2021 Jun 4;1(1):128-35.

[27] Setiono D. Hubungan Tipe Kepribadian Dengan Tingkat Stres Dalam Pengerjaan Tugas Akhir Pada Mahasiswa S1 Tingkat 4 Stikes Hang Tuah Surabaya Tahun Ajaran 2013/2014 [Internet] [Undergraduate Thesis]. [Jombang]: STIKes Insan Cendekia Medika Jombang; 2018 [cited 2021 Dec 20]. Available from: http://repo.stikesicmejbg.ac.id/3253/

[28] Diana L. HUBUNGAN ANTARA TIPE KEPRIBADIAN DENGAN TINGKAT STRES PADA MAHASISWA PROGRAM D4 KEBIDANAN FK UNPAD [Internet] [Undergraduate Thesis]. [Bandung]: Universitas Padjajaran; 2013 [cited 2021 Dec 20]. Available from: http://repository.unpad.ac.id/frontdoor/index/index/docld/11080

[29] Hakimi S, Hejazi E, Lavasani MG. The Relationships Between Personality Traits and Students' Academic Achievement. Procedia - Social and Behavioral Sciences. 2011;29:836-45. doi: 10.1016/j.sbspro.2011.11.312

[30] Sawitri AR, Widiasavitri PN. Strategi coping mahasiswa yang sedang menyusun skripsi di tengah pandemi COVID. Jurnal Psikologi Udayana. 2021;8(1):78-85. doi: 10.24843/JPU.2021.v08.i01.p08

[31] Cauberghe V, Van Wesenbeeck I, De Jans S, Hudders L, Ponnet K. How Adolescents Use Social Media to Cope with Feelings of Loneliness and Anxiety During COVID-19 Lockdown. Cyberpsychology, Behavior, and Social Networking. 2021 Apr 1;24(4):250-7. doi: 10.1089/cyber.2020.0478

[32] Eden AL, Johnson BK, Reinecke L, Grady SM. Media for Coping During COVID19 Social Distancing: Stress, Anxiety, and Psychological Well-Being. Front Psychol. 2020 Dec 18;11:577639. doi: 10.3389/fpsyg.2020.577639

[33] Rismala R, Novamizanti L, Ramadhani KN, Rohmah YS, Parjuangan S, Mahayana D. Kajian Ilmiah dan Deteksi Adiksi Internet dan Media Sosial di Indonesia Menggunakan XGBoost. JEPIN. 2021 Apr 12;7(1):1. doi: 10.26418/jp.v7i1.43606 
[34] Hartney E. How to Know If You Have an Internet Addiction and What to Do About It [Internet]. Verywell Mind. 17/09/2020. [cited 2021 Dec 20]. Available from: https://www.verywellmind.com/internet-addiction-4157289 